\title{
Comparison of Fuzzy Multi-Criteria Decision-Making Methods to Rank Business Strategies and Marketing Resources
}

\author{
Amirhossein Tohidi ${ }^{1}$, Mohammad Ghorbani ${ }^{1}$, Ali-Reza Karbasi ${ }^{1}$, Ahmadreza Asgharpourmasouleh ${ }^{2}$, Behrooz \\ Hassani-Mahmooei ${ }^{3}$ \\ ${ }^{1}$ Department of Agricultural Economics, Faculty of Agriculture, Ferdowsi University of Mashhad, Islamic \\ Republic of Iran \\ 2 Department of Social Sciences, Faculty of Letters and Humanities, Ferdowsi University of Mashhad, \\ Islamic Republic of Iran \\ ${ }^{3}$ Monash University, Melbourne, Australia
}

\begin{abstract}
Given the growing competition in domestic and international agricultural product markets, choosing a business strategy compatible with requirements of marketing resources can guide agro-food firms to maintain and enhance competitive advantages. However, this is not as simple as it seems because the decision-making criteria expressed in a fuzzy manner and the relationship between them can be hierarchical or network-based. Therefore, the main goal of this study was to select the most suitable business strategy and to prioritize marketing resources for one of the major agro-food firms in Iran. To ensure the robustness of the results, both fuzzy analytic hierarchy process (AHP) and fuzzy analytic network process (ANP) were applied to prioritize business strategies and marketing resources. The results of both methods revealed that the differentiation strategy had the highest priority in terms of the experts' viewpoints. The results also showed that managerial and customer relationship capabilities were the most important criteria in selecting the differentiation strategy. According to the findings of the study, for the successful implementation of the differentiation strategy, company managers are recommended to take the following three main elements into huge consideration: financial conditions, paying attention to customer's needs and requirements, and the introduction of new products and services.
\end{abstract}

\section{Keywords}

Agro-food, strategic management, problem-solving.

Tohidi, A., Ghorbani, M., Karbasi, A.-R., Asgharpourmasouleh, A. and Hassani-Mahmooei, B. (2020) "Comparison of Fuzzy Multi-Criteria Decision-Making Methods to Rank Business Strategies and Marketing Resources", AGRIS on-line Papers in Economics and Informatics, Vol. 12, No. 3, pp. 101-114. ISSN 1804-1930. DOI 10.7160/aol.2020.120309.

\section{Introduction}

Spices are produced from plant materials which are rich in vitamins, minerals, and antioxidants. Therefore, in many countries, spices are used in the food industry for coloring, preserving, and flavoring food products. Among a wide variety of spices, saffron is a rare and expensive spice extracted from the flower stigmas of Crocus sativus L., belonging to the family Iridaceae. Owing to its health benefits and flavor attributes, saffron is mainly used in the food industry. Currently, about $90 \%$ of saffron is produced in Iran (Khilare et al., 2019). However, the Iranian agricultural sector is faced with major problems of post-production; the main source of these problems is the lack of relevant business strategies
(Mohammadi et al., 2017). The development of a well-defined business strategy and the identification of important resources associated with it will help saffron companies perform better financially in both domestic and international markets; subsequently, they can achieve competitive advantages in these markets.

Over the past three decades, dramatic changes have occurred in the agro-food sector around the world, which has made agro-food markets increasingly competitive and complex. Due to these changes, agribusiness firms are facing new competitive pressures. Therefore, strategic management and planning of agro-food products is necessary to cope with these changes. In fact, each agro-food company should select and apply 
a business strategy that is tailored to the company's resources and capabilities (Chen et al., 2016). The goal of strategic management is to enable a firm to choose a strategy which can create a competitive advantage (Barney and Hesterly, 2015). There are several definitions of competitive advantage in the strategic management literature, each of which sometimes has a different meaning (Sigalas and Pekka Economou, 2013). In most definitions, there is an emphasis on the existence of a business strategy to achieve competitive advantage. A well-designed business strategy shifts the organization's focus onto environment, structures, and processes which affect how successfully a company meets its objectives (Yoshikuni and Albertin, 2018). Choosing the most appropriate business strategy is crucial because if a firm cannot recognize the linkage between operating decisions and business strategy, it may suffer a non-competitive production system which is costly and time-consuming to modify (Banchuen et al., 2017).

Although researchers have suggested different typologies of business strategy over the past decades (see Anwar and Hasnu, 2016, for more details), the generic strategies proposed by Porter (1980), namely cost leadership, differentiation, and focus are still applicable and widely used in the strategic management studies (e.g., Altuntas and Yilmaz, 2016; Balci et al., 2018; Goddard and Simm, 2017; Rexhepi and Srhoj, 2018). The term "generic" means all firms can potentially implement these types of strategies, regardless of whether they operate in the manufacturing, service or nonprofit sectors; in fact, any company active in any industry can choose and implement each of them (Hill and Jones, 2013). The cost leadership strategy is an integrated set of operations performed to produce goods or services which are acceptable to customers at a lower cost than rivals. The differentiation strategy is an integrated set of operations performed to produce goods or services with different features which are important to customers. A focus strategy involves an integrated set of activities for the production of goods or services which satisfy the needs of a particular industry segment (Hitt et al., 2016). Therefore, by implementing a focus strategy, companies can increase their shares through operating in a narrow niche market more efficiently than larger competitors (Ulubeyli et al., 2018). According to Porter's typology of generic strategies, a firm is unlikely to gain a competitive advantage if it fails to implement its strategy in at least one of the three generic strategies. Such a firm will effectively find itself "stuck in the middle", and will have low profitability (Grimmer, 2019).

The sustainable competitive advantage is the result of organizational resources which are the part of a business strategy and are essential for the overall firm performance (Bendickson and Chandler, 2019). Previous studies have shown that the performance of a firm depends on its resources (e.g. Altuntas and Yilmaz, 2016; Khan et al., 2019; Osakwe and Anaza, 2018; Sok et al., 2017). Indeed, in recent decades, scholarly attention has shifted from the strategic group perspective, which focuses on the strategic factors common among the industries, to the resource-based view (RBV) (Gomes et al., 2014). The RBV posits that the difference in the performance of companies over time is mainly due to their resources rather than the industry's structural characteristics (Hitt et al., 2016).

In general, in order to achieve superior performance, the firm resources must comply with the requirements of the business strategy (Wu et al., 2010b). Therefore, decisions based on the company's resources have a prominent role in the firm's strategy formulation process. Making such decisions may seem simple, but this, like other management tasks, is difficult and challenging and is tied to company success. Failure of half of the organizational decisions reflects the difficulty of decision-making process in this task (Hitt et al., 2016). Accordingly, an appropriate decision-making method is critical to the success of the organization and its competitive advantages. In order to make strategic decisions in a systematic and structured way, multiple criteria decisionmaking (MCDM) methods have been developed to rank strategic alternatives and to choose one over the other regarding several, sometimes conflicting, criteria (Haddad and Sanders, 2018). Based on RBV and Porter's model of generic strategies, some studies have been carried out to rank the business strategies using MCDM method. However, these studies have focused on manufacturing (Mohaghar et al., 2012), hospitality (Wu et al., 2010a) and service (Lin, Lee, and Chen, 2009; Lin, Lee, and $\mathrm{Wu}, 2009$; Lin and $\mathrm{Wu}, 2008$; Wu et al., 2010b) companies, but less attention has been given to those firms operating in agro-food industries. Therefore, the main contribution of this study was to prioritize business strategies and marketing resources for a major saffron firm in Iran. 
Making use of MCDM method can be helpful in choosing business strategies in the agricultural sector because decision-making in this economic sector is not based on simple and specific rules, but largely on decision-makers' knowledge and experience (Morris and Mishra, 2014). Decision-makers are believed to be more confident about interval judgments than fixed value ones. In fact, due to the fuzzy nature of the decisionmaking process, they cannot express their opinions clearly and explicitly (Koulinas et al., 2019). Hence, the next contribution of this study was to use fuzzy AHP and fuzzy ANP models to determine the most appropriate business strategy.

\section{Materials and methods}

Decision-making is a structured approach used to guide decision-makers to determine the best solution among different conflicting decisions by considering various sets of criteria at the same time (Deng and Jiang, 2018). Therefore, strategic decision-making is complex, particularly when several tangible and intangible criteria are considered simultaneously to select the best alternative (Adetunji et al., 2018). MCDM is an important branch of the modern decision theory, industrial engineering, and management systems which has many applications in various sciences (Guo and Zhao, 2017). It involves a set of approaches and methods which help decision-makers make better decisions (Mahmoudkelaye et al., 2018). Among the MCDM techniques, AHP and ANP are commonly used by researchers to rank and select business strategies (Gedela et al., 2018). AHP decomposes a complex decision problem into several levels which make a one-way hierarchical structure. In this structure, the goal, the criteria, and the alternatives are respectively located in the upper, middle and lower levels of the hierarchy. AHP is conceptually and practically simple, but in its hierarchical structure, its elements whose interactions are ignored are assumed to be independent of each other; it is not consistent with many real-world problems (Montesinos-Valera et al., 2017). Overcoming the limitations of AHP, ANP can incorporate more complex dependencies and interactions between elements within a decision context (Brožová et al., 2016; Hornická and Brožová, 2013). In conventional methods of MCDM such as AHP and ANP, however, the relative importance of criteria, sub-criteria, and alternatives is expressed as exact (crisp) numbers. Given the vague, fuzzy, and uncertain nature of human judgments in problem-solving, crisp numbers are believed not to be fully expressed or captured by the decision-makers' viewpoints, and therefore the use of conventional MCDM methods is not suitable to solve the real-world problems. To overcome this limitation, several methods have been developed by incorporating fuzzy set theory into MCDM problems. In fact, fuzzy multi-criteria decision-making (FMCDM) approaches are well suited to deal with uncertainty and vagueness of human thinking (Siddiquie et al., 2017). Therefore, in this study, fuzzy AHP and fuzzy ANP methods were applied to rank business strategies the descriptions of which are given below.

\section{Metamathematics of fuzzy logic}

A fuzzy number, represented by $\tilde{A}$, is a fuzzy subset of real numbers, and its membership function is expressed as $\mu \tilde{A}(x): R \rightarrow[0,1]$, where $x$ denotes the evaluated criteria set in a decision-making problem (Ashtiani and Abdollahi Azgomi, 2016). The membership degree function of a triangular fuzzy number (TFN) is expressed as follows (Hsieh et al., 2004):

$$
\mu_{\tilde{A}}(x)=\left[\begin{array}{cc}
(x-L) /(M-L), & L \leq x \leq M, \\
(U-x) /(U-M), & M \leq x \leq U, \\
0, & \text { otherwise },
\end{array}\right.
$$

where $L, \quad M, U$ are the upper, middle and lower bounds respectively. Thus, a TFN can be expressed as a triplet $(\mathrm{L}, \mathrm{M}, \mathrm{U})$ where $\mathrm{L} \leq \mathrm{M} \leq \mathrm{U}$. The mathematical operations of two TFNs, $\tilde{\mathrm{A}}_{1}=\left(\mathrm{L}_{1}, \mathrm{M}_{1}, \mathrm{U}_{1}\right)$ and $\tilde{\mathrm{A}}_{2}=\left(\mathrm{L}_{2}, \mathrm{M}_{2}, \mathrm{U}_{2}\right)$ are given in Table 1.

\begin{tabular}{|c|c|c|}
\hline Operation & Fuzzy equivalent & \\
\hline Addition & $\begin{array}{l}\tilde{A}_{1} \bigoplus \tilde{A}_{2}=\left(L_{1}, M_{1}, U_{1}\right) \bigoplus\left(L_{2}, M_{2}, U_{2}\right) \\
=\left(L+L_{2}, M_{1}+M_{2}, U_{1}+U_{2}\right)\end{array}$ & \\
\hline Multiplication & $\begin{array}{l}\tilde{A}_{1} \otimes \tilde{A}_{2}=\left(L_{1}, M_{1}, U_{1}\right) \otimes\left(L_{2}, M_{2}, U_{2}\right) \\
=\left(L_{1} L_{2}, M_{1} M_{2}, U_{1} U_{2}\right)\end{array}$ & $\begin{array}{l}\text { for } L_{i}>0, \\
M_{i}>0 \\
U_{i}>0\end{array}$ \\
\hline Subtraction & $\begin{array}{l}\tilde{A}_{1} \ominus \tilde{A}_{2}=\left(L_{1}, M_{1}, U_{1}\right) \ominus\left(L_{2}, M_{2}, U_{2}\right) \\
=\left(L_{1}-U_{2}, M_{1}-M_{2}, U_{1}-L_{2}\right)\end{array}$ & \\
\hline Division & $\begin{array}{l}\tilde{A}_{1} \oslash \tilde{A}_{2}=\left(L_{1}, M_{1}, U_{1}\right) \oslash\left(L_{2}, M_{2}, U_{2}\right) \\
=\left(L_{1} / U_{2}, M_{1} / M_{2}, U_{1} / L_{2}\right)\end{array}$ & $\begin{array}{l}\text { for } L_{i}>0, \\
M_{i}>0 \\
U_{i}>0\end{array}$ \\
\hline Reciprocal & $\tilde{A}_{l}^{-I}=\left(L_{l}, M_{l}, U_{l}\right)^{-I}=\left(1 / U_{l}, 1 / M_{l}, 1 / L_{l}\right)$ & $\begin{array}{l}\text { for } L_{i}>0, \\
M_{i}>0 \\
U_{i}>0\end{array}$ \\
\hline
\end{tabular}

Source: Hsieh et al. (2004)

Table 1: The mathematical operations of two TFNs.

In practically complex decision problems, where there is a degree of uncertainty and fuzziness in the decision-making process, making use of linguistic variables can be useful for evaluating 
criteria and alternatives. In fact, linguistic variables reflect human knowledge and experience which are often hard to quantify using exact numbers (Ashtiani and Abdollahi Azgomi, 2016). The values of a linguistic variable are not expressed numerically but are presented as words or sentences in a natural or artificial language (Hsieh et al., 2004). As shown in Table 2, criteria and alternatives were evaluated and ranked in this study using nine linguistic terms ranging from "equally important" to "extremely more important". Then, linguistic terms can be converted into fuzzy numbers using Figure 1 and Table 2 .

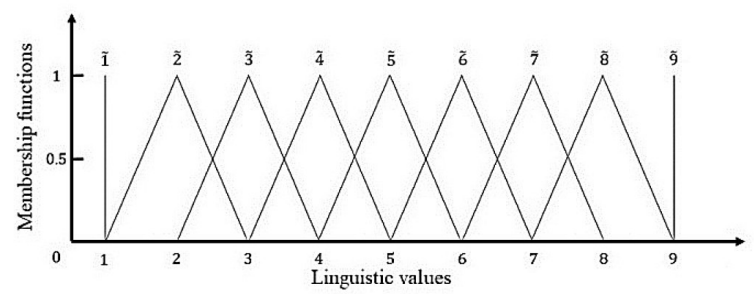

Source: Hsu et al. (2010)

Figure 1: Membership functions for linguistic values.

\begin{tabular}{|c|c|c|}
\hline $\begin{array}{l}\text { Fuzzy } \\
\text { number }\end{array}$ & Linguistic scales & $\begin{array}{c}\text { Scale of } \\
\text { fuzzy number }\end{array}$ \\
\hline$\tilde{1}$ & Equally important & $(1,1,1)$ \\
\hline$\tilde{2}$ & $\begin{array}{l}\text { Judgment values between equally and } \\
\text { moderately }\end{array}$ & $(1,2,3)$ \\
\hline$\widetilde{3}$ & Moderately more important & $(2,3,4)$ \\
\hline$\tilde{4}$ & $\begin{array}{l}\text { Judgment values between moderately and } \\
\text { strongly }\end{array}$ & $(3,4,5)$ \\
\hline$\tilde{5}$ & Strongly more important & $(4,5,6)$ \\
\hline$\widetilde{6}$ & $\begin{array}{l}\text { Judgment values between strongly and } \\
\text { very strongly }\end{array}$ & $(5,6,7)$ \\
\hline$\tilde{7}$ & Very strongly more important & $(6,7,8)$ \\
\hline$\widetilde{8}$ & $\begin{array}{l}\text { Judgment values between very strongly } \\
\text { and extremely }\end{array}$ & $(7,8,9)$ \\
\hline$\widetilde{9}$ & Extremely more important & $(9,9,9)$ \\
\hline
\end{tabular}

Source: own processing according to Hsu et al. (2010) and Lee et al. (2008).

Table 2: Fuzzy numbers based on linguistic terms.

\section{The fuzzy analytic hierarchy process}

Owing to the shortcomings of the AHP method in transforming subjective judgments into quantitative ones, the fuzzy AHP methodology was proposed and developed by the authors to solve the hierarchical decision problems in fuzzy environments. So far, various fuzzy AHP methods have been introduced in the FMCDM literature. However, some suggested methods such as Chang's (1996's) extent analysis have been criticized for not fully utilizing all the information on the fuzzy pairwise comparison matrices which may result in assigning an irrational zero weight to some useful decision criteria (Gul et al., 2017). The method proposed by Buckley (1985) does not have limitations of other techniques (Gul et al., 2017; Yazdi, 2017). Buckley's fuzzy AHP approach contains the following steps (Acar et al., 2018; Gul et al., 2017):

Step 1. Determination of criteria, sub-criteria, and alternatives in the framework of a hierarchical structure.

Step 2. Using linguistic expressions and uncertain numbers: fuzzy judgment matrices of pairwise comparisons are constructed in each of the hierarchy levels. In pairwise comparisons, each expert $\mathrm{k}$ determines which of the two criteria is more important and then assigns a linguistic value $a_{i j}$ to show the degree of the relative importance of a criterion over another.

$$
\tilde{A}^{k}=\left[\begin{array}{cccc}
\tilde{1} & \tilde{a}_{12} & \ldots & \tilde{a}_{1 n} \\
\tilde{a}_{21} & \tilde{1} & \cdots & \tilde{a}_{2 n} \\
\vdots & \vdots & \ddots & \vdots \\
\tilde{a}_{n 1} & \tilde{a}_{n 2} & \cdots & \tilde{1}
\end{array}\right]=\left[\begin{array}{cccc}
\tilde{1} & \tilde{a}_{12} & \ldots & \tilde{a}_{1 n} \\
1 / \tilde{a}_{12} & \tilde{1} & \ldots & \tilde{a}_{2 n} \\
\vdots & \vdots & \ddots & \vdots \\
1 / \tilde{a}_{1 n} & 1 / \tilde{a}_{2 n} & \cdots & \tilde{1}
\end{array}\right]
$$

In the above pairwise comparison matrix, if two criteria have the same importance, let $\tilde{1}=(1,1,1)$; the values of $\tilde{1}-\tilde{9}$ represent the relative importance of criterion $i$ with respect to the criterion $j$, and the values of $\tilde{1}^{-1}-\tilde{9}^{-1}$ reflect the relative importance of criterion $j$ as compared to criterion $i$.

Step 3. The aggregation of experts' preferences can only be done if their judgments are consistent. Therefore, the consistency rates are used to ensure that the experts' judgments are actually reliable. If consistency rates are less than or equal to 0.10 , judgments can be considered consistent.

Step 4. After confirming the consistency of judgments in every pairwise comparison matrix, experts' opinions can be aggregated using the geometric mean method. The resulting aggregate matrix is shown in Equation (3).

$\tilde{C}=\left[\begin{array}{cccc}\tilde{1} & \tilde{c}_{12} & \ldots & \tilde{c}_{1 n} \\ \tilde{c}_{21} & \tilde{1} & \ldots & \tilde{c}_{2 n} \\ \vdots & \vdots & \ddots & \vdots \\ \tilde{c}_{n 1} & \tilde{c}_{n 2} & \cdots & \tilde{1}\end{array}\right]$

Such as

$$
\tilde{c}_{i j}=\sqrt[q]{\prod_{k=1}^{q} \tilde{a}_{i j}^{k}}
$$


Where $k$ identifies the individual experts, and $q$ represents the total number of decision-makers.

Step 5. The fuzzy geometric mean for each row of the matrix is calculated using the geometric mean method.

$$
\tilde{r}_{i}=\left(\tilde{c}_{i 1} \otimes \tilde{c}_{i 2} \otimes \cdots \otimes \tilde{c}_{i n}\right)^{\frac{1}{n}}
$$

Step 6. The fuzzy weights of each criterion, sub-criterion, and alternatives are obtained as follows:

$$
\tilde{w}_{i}=\tilde{r}_{i} \otimes\left(\tilde{r}_{1} \oplus \tilde{r}_{2} \oplus \cdots \oplus \tilde{r}_{n}\right)^{-1}
$$

Where $\tilde{w}_{i}$ can be represented as a TFN, $\tilde{w}_{i}=\left(L w_{i}, M w_{i}, U w_{i}\right)$. Here, $L w_{i}, M w_{i}, U w_{i}$ are the upper, middle and lower bounds of the fuzzy weights respectively.

Step 7. The median method is applied to defuzzified fuzzy weights into crisp ones.

$$
w_{i}=\frac{L w_{i}+2 M w_{i}+U w_{i}}{4}
$$

Step 8. The crisp weights wi are normalized to calculate local priorities of the criteria. To obtain the global or overall priorities of the sub-criteria, their local priorities are multiplied by the weight of the covering criterion. Then, the final priority of the alternative $i \quad\left(S_{i}\right)$ is obtained using the Equation (8).

$$
S_{i}=\sum_{j=1}^{n} w_{j} S_{i j}, \forall i
$$

Where $w_{j}$ denotes the overall priority of the criterion $j$ and $s_{i j}$ represents the importance of the alternative $i$ according to the criterion $\mathrm{j}$.

\section{The fuzzy analytic network process}

Unlike the AHP method, ANP can consider the interrelationship between criteria in the decisionmaking process. Using the network analysis instead of the hierarchical structure, interrelations between decision-making criteria are measured in the ANP method. Like the conventional AHP, the ANP model cannot deal with the uncertainty and ambiguity inherent in human judgments. In addition to taking into account the interrelationship between criteria, the fuzzy ANP model also considers the uncertainty in the prioritization process of strategic choices. The fuzzy ANP model based on the Buckley's method contains the following steps (Sadeghi and Larimian, 2018):
Step 1. Determination of criteria, sub-criteria, and alternatives in the framework of a network structure.

Step 2. Like the fuzzy AHP method, weights of criteria, sub-criteria, and alternatives are determined based on the experts' judgments by performing pairwise comparisons between two clusters, or two elements, or two decision alternatives. Accordingly, Figure 1 and Table 2 are used to assess the relative importance of clusters and elements and their effects on each other.

Step 3. This step is performed in accordance with steps 3 and 4 in the fuzzy AHP method.

Step 4. Assuming the independence of the network factors from each other, the local priorities of each cluster and its elements are calculated according to the Buckley's method. Then, the fuzzy local weights are converted into crisp local priorities using the Equation (7).

Step 5. After aggregating the expert's judgments and calculating the local priorities of the components in the ANP network, these priorities are entered into the appropriate columns of an unweighted supermatrix. In the fuzzy ANP method, the unweighted supermatrix is used to express the relationships and interactions between the network components.

Step 6. To calculate a weighted or stochastic supermatrix (i.e. a matrix whose sum of column elements is equal to one), it is necessary to multiply the blocks of the unweighted supermatrix by the corresponding cluster weight. Then, the weighted supermatrix is raised to a sufficiently large power until convergence is achieved and the weights remain stable. The resulting matrix is known as the limit supermatrix, and it can measure all the direct and indirect effects between the elements and the clusters.

\section{Results and discussion}

In this study, data was collected from 30 company experts using a survey questionnaire based on pairwise comparisons between elements of a decision-making problem. Determination of a goal, criteria, sub-criteria, and alternatives is the first step in solving an MCDM problem. A variety of strategic frameworks can be considered decision-making options. However, the generic strategy framework of Porter is one of the most widely used tools to study the strategic behavior of organizations in business environments. Porter's 
framework of generic strategies is in line with other classifications. Accordingly, inferences derived from the Porter's strategy theory can also be obtained using other classifications (Wu et al., 2015). Therefore, in this study, Porter's generic strategies were used as decision-making alternatives.

Given the necessity of linkage between the business strategy and organization resources, the RBV was applied in this study to determine the criteria and sub-criteria of fuzzy AHP and fuzzy ANP methods. In general, market-based and marketing support resources are two types of value-creating resources. Market-based resources are those which can directly maintain or create competitive advantages and can be used immediately in the market, whereas marketing-support resources indirectly affect competitive advantages and have a supportive role for marketing activities. Among the market-based resources, customer relationship capabilities are the first and the most important source for each organization. Customer relationship capabilities include identifying the customers' needs and wants along with the ability to successfully establish relationships between them. The second set of market-based resources is the credibility and reputation of the firm among its suppliers and customers. This set is known as "reputational assets". Market innovation capabilities are the third most important market-based resource. Characteristics of market innovation capabilities include: complexity, relying on learning and tactile skills, the difficulty of identifying the causes of success and not being easily duplicated from one organization to another one. The human resources of the organization are another set of marketbased resources. In human resources literature, the emphasis has been placed on the importance of personnel management and staff development in increasing motivation and loyalty (Hooley et al., 2005).

Among the marketing support resources, managerial capabilities play a crucial role in supporting and underlying market-based resources. Managerial capabilities represent the management expertise and processes in the company for leveraging its market-based resources to gain a competitive advantage (Graves and Thomas, 2006).

Due to real-world empirical applications, the five criteria mentioned above have been accepted and used by researchers to select the most appropriate business strategy. Each of the assessment criteria consisting of several sub-criterion indications is shown in Figure 2. These sub-criteria have been selected based on the experts' opinions and previous studies (Altuntas and Yilmaz, 2016; Hooley et al., 2005; Lin, Lee, and Wu, 2009).

According to the instructions proposed for fuzzy AHP and fuzzy ANP methods, pairwise comparisons are made using linguistic variables and fuzzy numbers. It should be noted that internal relations between the five main criteria are considered in the fuzzy ANP method. Thus, the number of pairwise comparisons in the fuzzy ANP is 30 times more than that of the fuzzy AHP.

In the next step, after ensuring the consistency of judgment matrices for each expert, these matrices are aggregated using the geometric mean method (see Equation 4). For brevity, all aggregated pairwise comparison matrices are not reported in tables; only pairwise comparison matrix of main criteria is presented in Table 3 with respect to the goal .The TFNs located in the second row and the third column of Table 3 show that "managerial capabilities" are more important than the "customer relationship capabilities". In the fuzzy AHP method, crisp local priorities of the criteria are calculated using the equations (5), (6) and (7) (Table 4). In the fuzzy ANP method, the local weights form an unweighted supermatrix. Then, the blocks of this unweighted supermatrix are multiplied by the weight of the corresponding cluster to create a weighted supermatrix. The final weights in the fuzzy ANP method (which includes direct and indirect effects) are obtained by raising the weighted supermatrix to a sufficiently large power whose values for the main criteria are reported in Table 4.

According to Table 4, the results of the fuzzy AHP and fuzzy ANP methods indicate that "managerial capabilities" and "customer relationship capabilities" are more important than the other three criteria in choosing the most appropriate business strategy which is in accordance with the results of previous studies (Altuntas and Yilmaz, 2016; Wu et al., 2010b). In general, the success of agro-food firms depends largely on managerial capabilities because these capabilities are essential for identifying and developing market-based resources. Moreover, managerial capabilities are an important source of revenue growth for maintaining a competitive advantage. Therefore, managerial skills play a critical role in linking strategic decisions and business performance (Lorenzo et al., 2018).

As shown in Table 4, customer relationship 


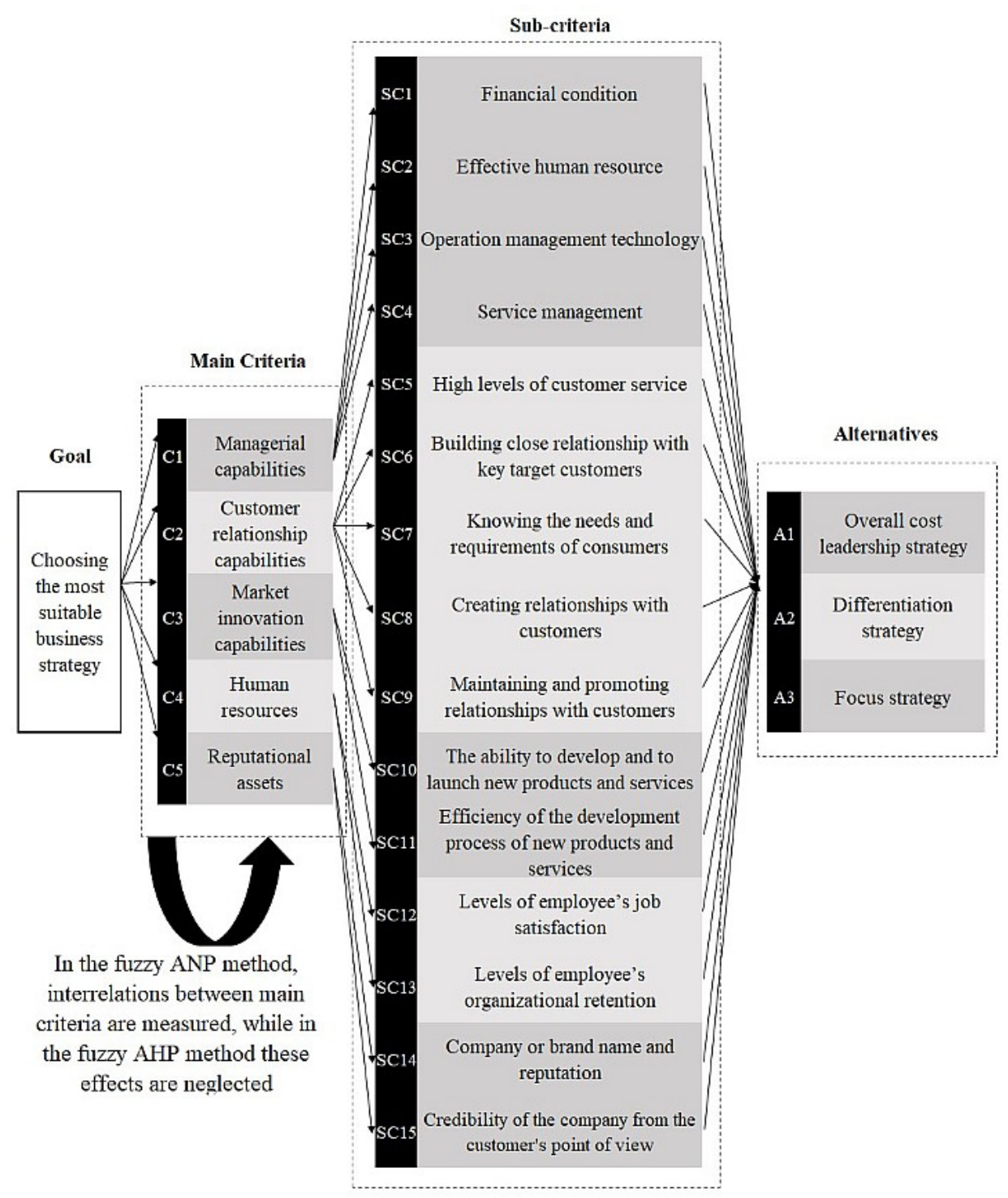

Source: own processing

Figure 2: A conceptual model of the strategic decision-making process.

\begin{tabular}{lccccc}
\hline Goal & C1 & C2 & C3 & C4 & C5 \\
\hline C1 & $(1.000,1.000,1.000)$ & $(1.131,1.621,2.174)$ & $(2.034,2.947,3.846)$ & $(2.359,3.160,4.082)$ & $(1.886,2.684,3.584)$ \\
C2 & $(0.460,0.617,0.884)$ & $(1.000,1.000,1.000)$ & $(1.630,2.363,3.141)$ & $(2.007,2.631,3.367)$ & $(1.570,2.232,2.917)$ \\
C3 & $(0.260,0.339,0.492)$ & $(0.318,0.423,0.613)$ & $(1.000,1.000,1.000)$ & $(0.753,1.025,1.416)$ & $(0.863,1.185,1.613)$ \\
C4 & $(0.245,0.316,0.424)$ & $(0.297,0.380,0.498)$ & $(0.706,0.975,1.328)$ & $(1.000,1.000,1.000)$ & $(0.745,1.112,1.578)$ \\
C5 & $(0.279,0.373,0.530)$ & $(0.343,0.448,0.637)$ & $(0.620,0.844,1.159)$ & $(0.634,0.899,1.341)$ & $(1.000,1.000,1.000)$ \\
\hline
\end{tabular}

Source: own processing (The symbols used in the table are defined in Figure 2).

Table 3: Aggregated fuzzy pairwise comparison matrix of main criteria with respect to the overall goal.

\begin{tabular}{lcc}
\hline Criteria & Fuzzy AHP & Fuzzy ANP \\
\hline Managerial capabilities & 0.366 & 0.304 \\
Customer relationship capabilities & 0.270 & 0.263 \\
Market innovation capabilities & 0.127 & 0.146 \\
Human resources & 0.118 & 0.149 \\
Reputational assets & 0.119 & 0.139 \\
\hline
\end{tabular}

Source: own processing

Table 4: The weights of the main criteria obtained from the fuzzy AHP and fuzzy ANP methods. 
capabilities are the second most important marketing resource in determining the business strategy. In fact, customer relationship capabilities represent the company's ability to build and develop close relationships with customers. Historically, in many business transactions little attention has been paid to establish a beneficial, long-term, and mutually beneficial relationship between the buyer and the seller. Today, agro-food firms should pay attention to consumers' demand and supply and the products that meet their needs. Hence, customer relationship capabilities have a significant impact on customer's loyalty and satisfaction, and consequently, the performance of an agro-food enterprise (Dentoni et al., 2014).

The results of the prioritization of the sub-criteria are reported in Table 5. Given the assumptions of the proposed model and the lack of interrelations between the sub-criteria, the values of the weights obtained from the fuzzy AHP method are the same as the ones calculated from the fuzzy ANP method.

As shown in Table 5, among the sub-criteria of "managerial capabilities", "financial condition" $(0.368)$ is perceived to be the most important factor for developing managerial competencies. In order to succeed, agro-food enterprises should have managers who analyze the financial conditions of the company and then make the necessary decisions to achieve the company's goals and to maintain a competitive advantage (Barnard et al., 2016).

According to Table 5, the final priorities indicate that "knowing the needs and requirements of consumers" (0.307) and "building close relationship with key target customers" (0.292) are the most important factors among the sub-criteria related to "customer relationship capabilities". A market-driven agro-food company seeks to build a long-term, close relationship with its target customers. The managers of this type of organization try to understand the expectations of target customers and meet their needs and requirements, both in the current and in the lifetime of the relationship. In market-driven agro-food firms, focusing on knowing target customers and building close relationships with them are the key drivers of all strategic organizational decisions (Barnard et al., 2016).

Concerning the criterion "market innovation capabilities", the results of Table 5 show that "the ability to develop and to launch new products and services" is more important than the "efficiency of the development process of new products and services". In today's competitive markets, innovative agro-food companies seek to introduce new products and services using marketing resources and business strategies. Successful agro-food firms can satisfy the changing needs of customers by launching new products and services. Market-driven agro-food enterprises are believed to achieve more success in introducing new products and services to consumers; it leads to more profitability (Mirzaei et al., 2016).

According to Table 5, "levels of employee's organizational retention" is much important than "levels of employee's job satisfaction". Having

\begin{tabular}{|c|c|c|}
\hline Criteria & Sub-criteria & Weights \\
\hline \multirow[t]{4}{*}{ Managerial capabilities } & Financial condition & 0.368 \\
\hline & Effective human resource & 0.246 \\
\hline & Operation management technology & 0.240 \\
\hline & Service management & 0.146 \\
\hline \multirow[t]{5}{*}{ Customer relationship capabilities } & High levels of customer service & 0.122 \\
\hline & Building close relationship with key target customers & 0.292 \\
\hline & Knowing the needs and requirements of consumers & 0.307 \\
\hline & Creating relationships with customers & 0.180 \\
\hline & Maintaining and promoting relationships with customers & 0.099 \\
\hline \multirow[t]{2}{*}{ Market innovation capabilities } & The ability to develop and to launch new products and services & 0.570 \\
\hline & Efficiency of the development process of new products and services & 0.430 \\
\hline \multirow[t]{2}{*}{ Human resources } & Levels of employee's job satisfaction & 0.478 \\
\hline & Levels of employee's organizational retention & 0.522 \\
\hline \multirow[t]{2}{*}{ Reputational assets } & Company or brand name and reputation & 0.540 \\
\hline & Credibility of the company from the customer's point of view & 0.460 \\
\hline
\end{tabular}

Source: own processing (The reported weights in the above table are the same for both fuzzy AHP and fuzzy ANP methods).

Table 5: The weights of the sub-criteria with respect to each criterion. 
adequate employees is essential for any company to achieve organizational goals. Several types of employees with a wide range of skills are employed in agricultural and food processing firms. Retaining employees is one of the main challenges agro-food companies are faced with because the recruitment of quality labor is time-consuming and costly (Ratković, 2015).

The results of Table 5 show that, in the reputational assets, "company or brand name and reputation" $(0.540)$ is more important than "credibility of the company from the customer's point of view" (0.460). Company/brand reputation stems from the consumer's opinion, so it reflects consumer's confidence in product quality which encourages the consumer to pay a price premium for labeled food and agricultural products. Brand name and reputation of the company are distinct from other elements of the marketing mix that represent quality, in that it indicates the cumulative effects of organizational marketing activities of a firm. If the brand of a company has a weak reputation, consumers will not trust that brand to buy (Lassoued and Hobbs, 2015). A study by Dantas et al. (2011) concluded that the brand name is one of the most important determinants of consumer food choice.

The relative importance of each of the sub-criteria, regardless of their criteria, is shown in Figure 3.
As shown in Figure 3, based on the final weights, "financial condition", "the ability to develop and to launch new products and services" and "knowing the needs and requirements of consumers" are more important than other sub-criteria to choose the most appropriate business strategy.

After prioritizing the criteria and sub-criteria, the relative priority of business strategies is determined in the last step using fuzzy AHP and fuzzy ANP models; the results are shown in Table 6.

The results of Table 6 indicate that, based on both fuzzy AHP and fuzzy ANP methods, "differentiation strategy" has the highest priority, "focus strategy" has the next highest priority, and "overall cost leadership strategy" has the lowest priority. Following differentiation strategy means that managers focus on creating a value-added company by offering products and services which are distinct from those of rivals. Agro-food firms can differentiate themselves from competitors in a variety of ways, including product performance, delivery, product quality, taste, packaging, customer service, technical expertise and image. In fact, whatever is important for consumers is a potential basis for differentiation in food and agricultural products and services (Barnard et al., 2016).

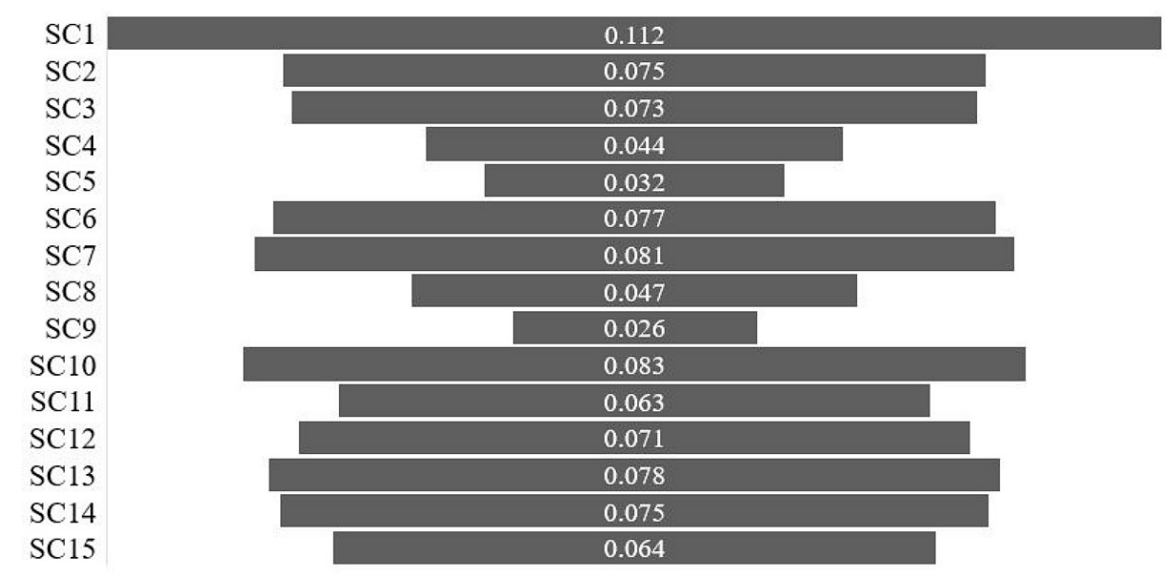

Source: own processing (The symbols are defined in Figure 2)

Figure 3: The relative importance of the sub-criteria.

\begin{tabular}{lccc}
\hline Business strategies & Fuzzy AHP & Fuzzy ANP & Ranking \\
\hline Overall cost leadership strategy & 0.289 & 0.290 & 3 \\
Differentiation strategy & 0.398 & 0.397 & 1 \\
Focus strategy & 0.313 & 0.313 & 2 \\
\hline
\end{tabular}

Source: own processing. 


\section{Conclusion}

Choosing the most appropriate business strategy is complex and even risky because it determines the behaviors, policies, plans, and projects of a company in the market. Hence, if the business strategy is not selected appropriately, the company fails to achieve its goals, which imposes significant costs to the organization. Given the growing competition in domestic and international agro-food markets, a well-designed business strategy is necessary for agribusiness firms to gain competitive advantages. However, a business strategy cannot be easily chosen by using a series of decision rules because (1) several criteria and sub-criteria play a role in the decision-making process, (2) these criteria can be related to each other, and (3) given the fuzzy and vague nature of information, decision-makers' judgments cannot be expressed using real numbers. FMCDM methods are effective tools to solve these problems. Thus, fuzzy AHP and fuzzy ANP methods were used to prioritize business strategies for a major saffron firm in Iran. The results of both methods showed that the differentiation strategy is the most suitable strategy for gaining competitive advantages. Therefore, various types of saffron products are recommended to be introduced on the market in various forms, such as cake, pudding, crème caramel, jelly, batter mixture, beverage, cream, etc. Moreover, improving the performance of production and customer service can differentiate the saffron brands and products from other business competitors in the marketplace. The results of the study revealed that management and customer relationship capabilities have the greatest impact on choosing a differentiation strategy. Understanding customer's needs and building close relationships with them are essential to ensure the success of new saffron products. In this context, managerial capabilities play a central role, for these capabilities have a demonstrable effect on supporting market-based resources. In general, considering the results of the study, it is suggested that agro-food managers should pay particular attention to three critical factors for the successful implementation of the differentiation strategy: (1) financial condition, (2) introduction of new products and services, and (3) knowing the needs and requirements of consumers.

\section{Corresponding authors}

Mohammad Ghorbani, Professor of Agricultural Economics

Faculty of Agriculture, Ferdowsi University of Mashhad, Azadi Square, Mashhad, Razavi Khorasan Province, Islamic Republic of Iran.

Phone:+985138805784,E-mail:ghorbani@um.ac.ir

\section{References}

[1] Acar, C., Beskese, A. and Temur, G. T. (2018) "Sustainability analysis of different hydrogen production options using hesitant fuzzy AHP”, International Journal of Hydrogen Energy, Vol. 43, No. 39, pp. 18059-18076. ISSN 0360-3199. DOI 10.1016/j.ijhydene.2018.08.024.

[2] Adetunji, O., Bischoff, J. and Willy, C. J. (2018) "Managing system obsolescence via multicriteria decision making”, Systems Engineering, Vol. 21, No. 4, pp. 307-321. ISSN 1098-1241. DOI $10.1002 /$ sys. 21436 .

[3] Altuntas, S. and Yilmaz, M. K. (2016) "Fuzzy DEMATEL Method to Evaluate the Dimensions of Marketing Resources: An Application in SMEs”, Journal of Business Economics and Management, Vol. 17, No. 3, pp. 347-364. ISSN 1611-1699. DOI 10.3846/16111699.2015.1068220.

[4] Anwar, J. and Hasnu, S. (2016) "Business strategy and firm performance: a multi-industry analysis", Journal of Strategy and Management, Vol. 9, No. 3, pp. 361-382. ISSN 1755-425X. DOI 10.1108/JSMA-09-2015-0071.

[5] Ashtiani, M. and Abdollahi Azgomi, M. (2016) "Trust modeling based on a combination of fuzzy analytic hierarchy process and fuzzy VIKOR”, Soft Computing, Vol. 20, No. 1, pp. 399-421. ISSN 1432-7643. DOI 10.1007/s00500-014-1516-1.

[6] Balci, G., Cetin, I. B. and Tanyeri, M. (2018) "Differentiation of container shipping services in Turkey", Transport Policy, Vol. 61, No. 26-35. ISSN 0967-070X. DOI 10.1016/j.tranpol.2017.10.004. 
[7] Banchuen, P., Sadler, I. and Shee, H. (2017) "Supply chain collaboration aligns order-winning strategy with business outcomes", IIMB Management Review, Vol. 29, No. 2, pp. 109-121. ISSN 0970-3896. DOI 10.1016/j.iimb.2017.05.001.

[8] Barnard, F. L., Foltz, J. C. and Yeager, E. A. (2016) “Agribusiness management", 5" ed., London, Routledge, ISBN 1315709422. DOI 10.4324/9781315709420.

[9] Barney, J. B. and Hesterly, W. S. (2015) "Strategic Management and Competitive Advantage Concepts and Cases", 5 ${ }^{\text {th }}$ ed., Edinburgh Gate Harlow, Pearson Education Limited. ISBN 0133127400.

[10] Bendickson, J. S. and Chandler, T. D. (2019) “Operational performance: The mediator between human capital developmental programs and financial performance”, Journal of Business Research, Vol. 94, No. 162-171. ISSN 0148-2963. DOI 10.1016/j.jbusres.2017.10.049.

[11] Brožová, H., Šup, L., Rydval, J., Sadok, M. and Bednar, P. (2016) "Information security management: ANP based approach for risk analysis and decision making", Agris On-line Papers in Economics and Informatics, Vol. 8, No. 1, pp. 13-23. ISSN 1804-1930. DOI 10.7160/aol.2016.080102.

[12] Chen, C. C., Yueh, H. P. and Liang, C. (2016) "Strategic management of agribusiness: Determinants and trends", Journal of Entrepreneurship, Management and Innovation, Vol. 12, No. 4, pp. 69-90. ISSN 2299-7326.DOI 10.7341/20161244.

[13] Dantas, M. I. S., Nakajima, V., Rosa, D. D., Andrade, F. O., Camila, C. and Martino, H. S. D. (2011) "Guava jam packaging determinant attributes in consumer buying decision", Ciencia e Tecnologia de Alimentos, Vol.31, No.3,pp. 567-570. ISSN 0101-2061. DOI 10.1590/S0101-20612011000300003.

[14] Deng, X. and Jiang, W. (2018) “An Evidential Axiomatic Design Approach for Decision Making Using the Evaluation of Belief Structure Satisfaction to Uncertain Target Values", International Journal of Intelligent Systems, Vol. 33, No. 1, pp. 15-32. ISSN 0884-8173. DOI 10.1002/int.21929.

[15] Dentoni, D., English, F. and Schwartz, D. (2014) "The impact of public R\&D on marketing and supply chains on small farms' market sensing capability: Evidence from the Australian seafood industry", International Food and Agribusiness Management Review, Vol. 17, No. 1, pp. 37-58. ISSN 1559-2448. DOI 10.22004/ag.econ.163353.

[16] Gedela, R. K., Mohan, K. K. and Prasad, V. K. (2018) “Application of BOCR models in service oriented architecture (SOA): study on model validation through quantification for QoS considerations", International Journal of Systems Assurance Engineering and Management, Vol. 9, No. 6, pp. 1346-1354. ISSN 0975-6809. DOI 10.1007/s13198-018-0751-8.

[17] Goddard, A. and Simm, A. (2017) "Management accounting, performance measurement and strategy in English local authorities", Public Money and Management, Vol. 37, No. 4, pp. 261-268. ISSN 0954-0962. DOI 10.1080/09540962.2017.1295726.

[18] Gomes, C. F., Yasin, M. M., Lisboa, J. V. and Small, M. H. (2014) "Discerning competitive strategy through an assessment of competitive methods", Service Industries Journal, Vol. 34, No. 12 , pp. 974-998. ISSN 0264-2069. DOI 10.1080/02642069.2014.915946.

[19] Graves, C. and Thomas, J. (2006) "Internationalization of Australian family businesses: A managerial capabilities perspective”, Family Business Review, Vol. 19, No. 3, pp. 207-224. ISSN 0894-4865. DOI 10.1111/j.1741-6248.2006.00066.x.

[20] Grimmer, L. (2019) "2 - Disrupting the giants: How independent grocers respond to the supermarket duopoly in Tasmania, Australia”, Woodhead Publishing. ISBN 978-0-08-102037-1.

[21] Gul, M., Ak, M. F. and Guneri, A. F. (2017) "Occupational health and safety risk assessment in hospitals: A case study using two-stage fuzzy multi-criteria approach", Human and Ecological Risk Assessment: An International Journal, Vol. 23, No. 2, pp. 187-202. ISSN 1080-7039. DOI 10.1080/10807039.2016.1234363.

[22] Guo, S. and Zhao, H. (2017) "Fuzzy best-worst multi-criteria decision-making method and its applications", Knowledge-Based Systems, Vol. 121, No. 23-31. ISSN 0950-7051. DOI 10.1016/j.knosys.2017.01.010. 
[23] Haddad, M. and Sanders, D. (2018) "Selection of discrete multiple criteria decision making methods in the presence of risk and uncertainty", Operations Research Perspectives, Vol. 5, No. 357-370. ISSN 2214-7160. DOI 10.1016/j.orp.2018.10.003.

[24] Hill, C. W. L. and Jones, G. R. (2013) "Strategic management: An integrated approach", 10" ed., Mason, OH, South-Western, Cengage Learning, ISBN 1133485707.

[25] Hitt, M. A., Ireland, R. D. and Hoskisson, R. E. (2016) "Strategic management: Concepts and cases: Competitiveness and globalization”, 12 $2^{\text {th }}$ ed., Boston, Cengage Learning, ISBN 1305856287.

[26] Hooley, G. J., Greenley, G. E., Cadogan, J. W. and Fahy, J. (2005) "The performance impact of marketing resources", Journal of Business Research, Vol. 58, No. 1 Spec. Iss., pp. 18-27. ISSN 01480-2963. DOI 10.1016/S0148-2963(03)00109-7.

[27] Hornická, A. and Brožová, H. (2013) "Continuity of demarcation process of the regions for concentrated state support”, Agris On-line Papers in Economics and Informatics, Vol. 5, No. 3, pp. 3-12. ISSN 1804-1930. DOI 10.22004/ag.econ.157520.

[28] Hsieh, T.-Y., Lu, S.-T. and Tzeng, G.-H. (2004) "Fuzzy MCDM approach for planning and design tenders selection in public office buildings", International Journal of Project Management, Vol. 22, No. 7, pp. 573-584. ISSN 0263-7863. DOI 10.1016/j.ijproman.2004.01.002.

[29] Hsu, Y.-L., Lee, C.-H.,and Kreng, V. B. (2010) "The application of Fuzzy Delphi Method and Fuzzy AHP in lubricant regenerative technology selection", Expert Systems with Applications, Vol. 37, No. 1, pp. 419-425. ISSN 0957-4174. DOI 10.1016/j.eswa.2009.05.068.

[30] Khan, S. Z., Yang, Q. and Waheed, A. (2019) "Investment in intangible resources and capabilities spurs sustainable competitive advantage and firm performance", Corporate Social Responsibility and Environmental Management, Vol. 26, No. 2, pp. 285-295. ISSN 1535-3958. DOI $10.1002 / \operatorname{csr} .1678$.

[31] Khilare, V., Tiknaik, A., Prakash, B., Ughade, B., Korhale, G., Nalage, D., Ahmed, N., Khedkar, C. and Khedkar, G. (2019) "Multiple tests on saffron find new adulterant materials and reveal that $1^{\text {st }}$ grade saffron is rare in the market", Food Chemistry, Vol. 272, No. 635-642. ISSN 0308-8146. DOI 10.1016/j.foodchem.2018.08.089.

[32] Koulinas, G. K., Marhavilas, P. K., Demesouka, O. E., Vavatsikos, A. P. and Koulouriotis, D. E. (2019) "Risk analysis and assessment in the worksites using the fuzzy-analytical hierarchy process and a quantitative technique - A case study for the Greek construction sector", Safety Science, Vol. 112, No. 96-104. ISSN 0925-7535. DOI 10.1016/j.ssci.2018.10.017.

[33] Lassoued, R. and Hobbs, J. E. (2015) "Consumer confidence in credence attributes: The role of brand trust”, Food Policy, Vol. 52, No. 99-107. ISSN 0306-9192. DOI 10.1016/j.foodpol.2014.12.003.

[34] Lee, A. H., Chen, W.-C. and Chang, C.-J. (2008) "A fuzzy AHP and BSC approach for evaluating performance of IT department in the manufacturing industry in Taiwan", Expert Systems with Applications, Vol. 34, No. 1, pp. 96-107. ISSN 0957-4174. DOI 10.1016/j.eswa.2006.08.022.

[35] Lin, C.-T., Lee, C. and Chen, W.-Y. (2009) "Using fuzzy analytic hierarchy process to evaluate service performance of a travel intermediary", Service Industries Journal, Vol. 29, No. 3, pp. 281-296. ISSN 0264-2069. DOI 10.1080/02642060701846762.

[36] Lin, C.-T., Lee, C. and Wu, C.-S. (2009) "Optimizing a marketing expert decision process for the private hotel", Expert Systems with Applications, Vol. 36, No. 3, pp. 5613-5619. ISSN 0957-4174. DOI 10.1016/j.eswa.2008.06.113.

[37] Lin, C. T. and Wu, C. S. (2008) "Selecting a marketing strategy for private hotels in Taiwan using the analytic hierarchy process", Service Industries Journal, Vol. 28, No. 8, pp. 1077-1091. ISSN 0264-2069. DOI 10.1080/02642060802187991.

[38] Lorenzo, J. R. F., Rubio, M. T. M. and Garcés, S. A. (2018) "The competitive advantage in business, capabilities and strategy. What general performance factors are found in the Spanish wine industry?", Wine Economics and Policy, Vol. 7, No. 2, pp. 94-108. ISSN 2213-3968. DOI 10.1016/j.wep.2018.04.001. 
[39] Mahmoudkelaye, S., Azari, K. T., Pourvaziri, M. and Asadian, E. (2018) "Sustainable material selection for building enclosure through ANP method", Case Studies in Construction Materials, Vol. 9, No. ISSN 2214-5095. DOI 10.1016/j.cscm.2018.e00200.

[40] Mirzaei, O., Micheels, E. T. and Boecker, A. (2016) "Product and marketing innovation in farmbased businesses: the role of entrepreneurial orientation and market orientation", International Food and Agribusiness Management Review, Vol. 19, No. 2, pp. 99-130. ISSN 1559-2448. DOI 10.22004/ag.econ.234958.

[41] Mohaghar, A., Fathi, M. R., Zarchi, M. K. and Omidian, A. (2012) "A combined VIKOR-fuzzy AHP approach to marketing strategy selection”, Business Management and Strategy, Vol. 3, No. 1, pp. 13-27. ISSN 2157-6068. DOI 10.5296/bms.v3i1.957.

[42] Mohammadi, H., Saghaian, S.,and Alizadeh, P. (2017) "Prioritization of expanded marketing mix in different stages of the product life cycle: the case of food industry", Journal of Agricultural Science and Technology, Vol. 19, No. 5, pp. 993-1003. ISSN 1680-7073.

[43] Montesinos-Valera, J., Aragonés-Beltrán, P. and Pastor-Ferrando, J.-P. (2017) "Selection of maintenance, renewal and improvement projects in rail lines using the analytic network process", Structure and Infrastructure Engineering, Vol. 13, No. 11, pp. 1476-1496. ISSN 1573-2479. DOI 10.1080/15732479.2017.1294189.

[44] Morris, W. and Mishra, N. (2014) "Online decision support system for finished lamb production”, International Journal of Services, Economics and Management, Vol. 6, No. 3, pp. 209-221. ISSN 1753-0822. DOI 10.1504/IJSEM.2014.064296.

[45] Osakwe, C. N. and Anaza, N. A. (2018) "Understanding marketing resources and size in agro-based enterprises", Marketing Intelligence and Planning, Vol. 36, No. 2, pp. 230-244. ISSN 0263-4503. DOI 10.1108/MIP-07-2017-0149.

[46] Ratković, T. (2015) "HRM in foreign-owned agricultural and food processing companies in Serbia", Economics of Agriculture, Vol. 62, No. 2, pp. 353-367. ISSN 0352-3462. DOI 10.22004/ ag.econ.206922.

[47] Rexhepi, G. and Srhoj, S. (2018) "Strategy as an ever evolving road to success of growing enterprises", World Review of Entrepreneurship, Management and Sustainable Development, Vol. 14, No. 3, pp. 333-347. ISSN 1746-0573. DOI 10.1504/WREMSD.2018.091689.

[48] Sadeghi, A. and Larimian, T. (2018) "Sustainable electricity generation mix for Iran: A fuzzy analytic network process approach", Sustainable Energy Technologies and Assessments, Vol. 28, No. 30-42. ISSN 2213-1388. DOI 10.1016/j.seta.2018.04.001.

[49] Siddiquie, R. Y., Khan, Z. A. and Siddiquee, A. N. (2017) "Prioritizing decision criteria of flexible manufacturing systems using fuzzy TOPSIS", Journal of Manufacturing Technology Management, Vol. 28, No. 7, pp. 913-927. ISSN 1741-038X. DOI 10.1108/JMTM-04-2017-0069.

[50] Sigalas, C. and Pekka Economou, V. (2013) "Revisiting the concept of competitive advantage: Problems and fallacies arising from its conceptualization", Journal of Strategy and Management, Vol. 6, No. 1, pp. 61-80. ISSN 1755-425X. DOI 10.1108/17554251311296567.

[51] Sok, P., Snell, L., Lee, W. J. T. and Sok, K. M. (2017) "Linking entrepreneurial orientation and small service firm performance through marketing resources and marketing capability: A moderated mediation model", Journal of Service Theory and Practice, Vol. 27, No. 1, pp. 231-249. ISSN 2055-6225. DOI 10.1108/JSTP-01-2016-0001.

[52] Ulubeyli, S., Kazaz, A. and Sahin, S. (2018) "Survival of construction SMEs in macroeconomic crises: Innovation-based competitive strategies", Journal of Engineering, Design and Technology, Vol. 16, No. 4, pp. 654-673. ISSN 1726-0531. DOI 10.1108/JEDT-03-2018-0057.

[53] Wu, C.-S., Lin, C.-T. and Lee, C. (2010a) “Competitive marketing strategies decision-making based on marketing resources and capabilities: Evidence from the hospitality industry in Taiwan", Journal of Quality Assurance in Hospitality and Tourism, Vol. 11, No. 4, pp. 219-238. ISSN 1528-008X. DOI 10.1080/1528008X.2010.504163. 
[54] Wu, C.-S., Lin, C.-T., and Lee, C. (2010b) "Optimal marketing strategy: A decision-making with ANP and TOPSIS", International Journal of Production Economics, Vol. 127, No. 1, pp. 190-196. ISSN 0925-5273. DOI 10.1016/j.jpe.2010.05.013.

[55] Wu, P., Gao, L. and Gu, T. (2015) "Business strategy, market competition and earnings management: Evidence from China", Chinese Management Studies, Vol. 9, No. 3, pp. 401-424. ISSN 1750-614X. DOI 10.1108/CMS-12-2014-0225.

[56] Yazdi, M. (2017) "Hybrid Probabilistic Risk Assessment Using Fuzzy FTA and Fuzzy AHP in a Process Industry", Journal of Failure Analysis and Prevention, Vol. 17, No. 4, pp. 756-764. ISSN 1547-7029. DOI 10.1007/s11668-017-0305-4.

[57] Yoshikuni, A. C. and Albertin, A. L. (2018) "Effects of strategic information systems on competitive strategy and performance", International Journal of Productivity and Performance Management, Vol. 67, No. 9, pp. 2018-2045. ISSN 1741-0401. DOI 10.1108/IJPPM-07-2017-0166. 